\title{
Does Financial Development Enhance Foreign Trade in Selected Transitional Economies?
}

\author{
Kunofiwa Tsaurai \\ Ph.D., Associate Professor at the University of South Africa \\ Department of Finance, Risk Management and Banking, Pretoria, South Africa \\ e-mail: kunofiwa.tsaurai@gmail.com
}

\author{
Patience Hlupo \\ Lecturer at Bindura University of Technology, Bindura, Zimbabwe \\ e-mail:phlupo@gmail.com
}

\begin{abstract}
The study investigates the influence of financial development on foreign trade in transitional economies using panel data (1994-2014). Although empirical studies on the impact of financial development on foreign trade are available, none of them that the authors are aware of attempted to explore the subject matter in the context of transitional economies. None attempted to investigate if human capital development is a channel through which financial development influences foreign trade or international trade. Under fixed effects, financial development was found to have a non-significant positive influence on foreign trade, while the random effects approach shows a significant positive relationship running from financial development towards foreign trade. The findings resonate with the majority of the literature on the subject. However, pooled ordinary least squares (OLS) shows that financial development had a significant negative influence on foreign trade.

Under both fixed and random effects, human capital development was found to be a channel through which financial development had a significant positive effect on foreign trade. The results are in line with Patrick's (1966) argument that foreign trade is quickened by high levels of human capital and financial development. The implication of the study is that transitional authorities should develop and implement human capital development enhancement policies in order to enable financial development to have a significant positive effect on foreign trade. In contrast to the available literature, human capital development was found to have had a significant negative impact on foreign trade under the OLS approach. Future studies on the subject matter should address the endogeneity concerns and the dynamic characteristics of the foreign trade data.
\end{abstract}


Keywords: Financial Development, Foreign trade, Transitional Economies, Panel Data

JEL: G15, J24, P45, P2

\section{Introduction}

Globalization, economic integration, financial liberalization, and technological development all seem to dictate that interdependence among countries is unavoidable and, critically, the order of the day. Financial liberalization, among others, has been a widespread phenomenon in many economies. Equally, more effort and expenditure are being spent on human capital development as one of the 17 sustainable development goals. Hence, foreign trade is an inevitable outcome of such developments. Foreign trade is essential in that it contributes to economic growth directly (Akeem 2011; Edoumiekumo and Opukri 2013), or indirectly through either financial development (Gokmenoglu et al. 2015) or human capital development (Haq and Luqman 2014). Consequently, studies on the determinants of foreign trade are abundant (Ghanbari and Ahmadi 2017; Mete and Bozgeyik 2017). Research evidence on the individual effects of financial development and human capital on foreign trade abounds (Paravisini et al. 2011; Manova 2013; Shahbaz and Rahman 2014).

Likewise, human capital accumulation plays a vital role in a country's international competitiveness, as global economic progress centers on knowledge (Domenico et al. 2009). It generates an absolute advantage and a temporary monopoly until such a time when other countries can match the level of human capital development. This positive link between human capital and foreign trade is important in this study.

Some researchers dwell on the complementarity of financial development and human capital (Hakeem and Oluwatoyin 2012; Zaman et al. 2012; Sehrawat and Giri 2014; Eryigit and Dulgeroglu 2015; Tsaurai 2018). It is argued that financial development makes it easy to accumulate human capital (Abubakar et al. 2015; Kargbo et al. 2016). To be more elaborate, the link between human capital and financial development forms a vicious cycle where increased access to finance is a means for human capital accumulation. The latter also stimulates better usage of financial resources, with the ability to save or invest professed to rise with the level of human capital development (Evans et al. 2002).

This background is the basis for the current study. It not only investigates the influence on financial development on foreign trade, but it also explores how human capital and financial development complement each other to foster foreign trade. 


\section{The impact of financial development on foreign trade - the theoretical literature}

The first theoretical underpinning that explains the channel through which finance impacts foreign trade is trade finance theory (Vaubourg 2016). Firms involved in foreign trade have a choice among a variety of trade finance options, which include open accounts, cash in advance, letters of credit, and export credit guarantees. Cash in advance works well with low finance costs in the importer's country and robust contract enforcement mechanisms in the exporter's country. An open account is suitable when finance costs are low in the exporter's country and when robust enforcement mechanisms exist in the importer's country. Letters of credit and export credit guarantees are safe modes of payment that make trade more attractive, especially to the exporter. Thus, the importer (exporter) imports (exports) more when payment terms are favorable.

The second theoretical perspective holds that variable and fixed costs associated with foreign trade are high, and internal finance may not be enough to cover them. When a firm expands its operations to serve foreign markets, it requires more capital to cover upfront costs like research and development, customizing the product, and establishing distribution channels (Baldwin and Krugman 1989). Inevitably, exporting firms resort to external finance to cover the gap (Vaubourg 2016). Imperfections in capital markets delay firms' decisions to go international. Firms find it difficult to buy equipment and more raw materials that allow them to scale up operations for export trade. Hence, while the production scale remains low, the export business remains less feasible. As firms wait to grow organically through ploughing back profits, the country's share of foreign trade is reduced in the meantime. So, it can be argued that less developed financial markets do not favor foreign trade and vice versa.

The above viewpoint resonates with factor endowment theory, which asserts that firms overcome illiquidity problems by exporting goods that are highly dependent on external finance, thereby improving the structure and balance of trade (Rajan and Zingales 1998). Rajan and Zingales argued that developing financial systems are a way to deal with moral hazard and adverse selection in so doing attracting external finance and growing exports.

Bardhan and Kletzer's (1987) model advocates a link between foreign trade and financial development. The primary focus of the model is on mobilizing and investing financial resources. The intermediate goods sector is said to require less foreign capital, while the final goods sector depends more on external capital to fund its working capital needs. As such, a developed financial system allows for the efficient mobilization of external capital by reducing information asymmetry and moral hazard, which benefits firms specializing in final goods. Therefore, a less developed financial system justifies the involvement of firms in the intermediate goods sector in foreign trade while well-developed financial systems provide a comparative advantage for firms to specialize in trading finished goods. This model is further extended by Beck (2002), who 
shows that even when two different sectors rely on external finance, trade patterns for manufactured goods are largely dependent on the level of financial development.

A similar theoretical model by Baldwin and Krugman (1989) supports the above view. They assert that developed financial systems allow for risk reduction through diversification, making it possible for a country to specialize and trade in a risky good than is the case when risk premium is high. Underdeveloped financial markets find it difficult to diversify away risk, and hence they opt to trade in low-risk or risk-free goods, since they pay high-risk premiums. To this end, the nature of trade between any two countries is dependent upon dissimilarities in levels of financial development.

In the same vein, the liquidity easing theoretical angle contends that greater liquidity in the market comes with better financial development as the speed of trading and settling transactions increases (Ezeoha and Cattaneo 2012), thus making it possible for firms to trade internationally. Fundamentally, finance-trade theory comes in two clusters: the demand-following hypothesis and the supply-leading view, where the former relates to causal links from trade to finance while the latter relates to causal links from finance to trade.

\section{The effect of financial development on foreign trade - the empirical literature}

Empirical evidence on the relationship between financial development and trade is two-pronged. Initially, there was a group of researchers who found a positive link between financial development and foreign trade. One study by Hur et al. (2006) investigated the extent to which different industries in different countries depended on external finance given asset tangibility. Their results show that developed financial markets stimulate more export business for intangible assets. A recent study by Choi (2018) also confirms a positive relationship between financial development and trade. Considering asset tangibility, study findings show that more asset tangibility attracts external finance and enhances export activity for countries with developed financial markets.

Hanh (2010) used time-series data from 1994-2008 to test the existence of causal effects between financial development, foreign trade, and economic growth for 29 countries. The results support the feedback hypothesis on the link between trade and financial openness in Asia. Another study by Waqas et al. (2011) studied the long-run linkages between economic growth, foreign trade, and financial development in $\mathrm{Pa}$ kistan. A bounds test showed a long-run relationship between financial development and foreign trade in Pakistan, which is confirmed by Granger causality tests, running from financial development to foreign trade. Analogously, empirical evidence from Bangladesh found bidirectional causality between domestic credit and trade openness (Hassan and Islam 2005). 
Further evidence from Kiendrebeogo (2013) supports this positive effect. Using a gravity model to investigate the negative effect of financial crises on exports, they sampled 75 countries and studied how their exports responded to demand and supply shocks in the financial sector from 1988 to 2010. Their results show that as a financial crisis deepens, the level of bilateral trade falls. The effect is more marked for countries that export manufactured goods and those dependent on external finance. Their conclusions are robust, even after controlling for different estimation approaches, endogenous factors, and the existence of outliers.

Kumarasamy and Singh (2018) made a different analysis relating to the effect of financial development on a firm's capability to enter export markets. Their study utilized World Bank Enterprise Survey data for Asia-Pacific countries and concluded that developed financial markets make it easy and possible for firms to start exporting. Fauceglia (2015) conducted a study on 17 developing countries to examine the impact of credit constraints on exporting. The findings show that credit constraints inhibit firms from exporting, with a greater effect on less developed countries. Their results also suggest that credit constraints have a larger negative impact on firms in the technology sector, which rely more on external finance. More support on the effect of credit constraints on trade is found in the works of Brooks and Dovis (2019).

Another analogous study by Manova (2013) linked external credit constraints to productivity. He found that beyond a certain productivity threshold, firms start obtaining external finance to cover their fixed costs. Higher productivity enables firms to meet high finance costs related to external finance, which is necessary to cover export fixed costs. The study determined that low productivity firms are constrained to export as they cannot afford credit that would allow them to partly cover their variable costs. In line with this, Becker et al. (2013) demonstrated that modern financial systems are a source of comparative advantage to firms reliant on external finance to further their export business. Examining more than 170 countries, they collected bilateral trade data between 1970 and 1988. From OLS regression analysis, they determined that developed financial systems nurture export growth.

Cross country evidence on the link between financial development and foreign trade from a study by Leibovici (2018) provides a different lens through which to view the nexus. He suggests that developed financial systems reallocate a country's share of foreign trade from labor-intensive to capital-intensive industries, which are highly dependent on external finance. The probability of venturing into the export business positively and significantly correlates with the leverage ratio, the liquidity ratio, and collateralizable assets in Berman and Héricourt's (2010) study.

Using a different approach, the study by Engel et al. (2013) focused on how financial constraints impacted a firm's decision to terminate its export business. Like Bellone et al. (2010), they used yearly data from French companies but over a shorter period, from 2000-2002. They found that the higher a firm's leverage ratio, the higher its probability of exiting exports, and the lower the firm's cashflow ratio, the higher the possibility of terminating export operations. Italian evidence from a study by Forlani 
(2010) found from 1999-2005 data that higher liquidity levels allow a firm to expand its export market. In line with this finding, Muûls' (2012) investigation on Belgian firms proved, from OLS regression analysis, that low default risk firms are more likely to expand their exporting destinations. The same determination is made by Askenazy et al. (2011), who found a negative effect of financial vulnerability on the number of export destinations from a French study covering 1996-2006.

Research evidence from Italian firms shows that the low supply of credit can negatively affect export trade (Minetti and Zhu 2011). Cross-sectional data for 2001 was used. A firm faced credit constraints when its demand for credit exceeded its actual borrowing. Firms faced with a financing gap exported a minimum of $38 \%$ less than those who obtained enough credit and with a chance of exporting $39 \%$ below that of unconstrained firms. Likewise, the credit statistics of Peruvian firms for the period July 2007 to June 2009 corroborate this finding (Paravisini et al. 2011).

The second strand of research found no link between financial development and foreign trade. Babatunde and Fowowe (2012) refute the finance-led trade hypothesis in Sub Saharan Africa. Consistent with this stance, the results from Berman and Héricourt's (2010) study on the effects of financial characteristics on export levels proves the insignificant impact of the leverage ratio, the liquidity ratio, and collateralizable assets on the quantity of exports. Overall, the empirical evidence supports the theoretical literature that a financial crisis intensifies the negative effects of financial constraints on foreign trade (Vaubourg 2016).

\section{Is human capital development a channel through which financial development influences foreign trade?}

The extant literature provides substantial evidence on the positive interaction effects between financial development and human capital on GDP (Ukenna et al. 2010; Abubakar et al. 2015; Kargbo et al. 2016). Kendall (2007) established that human capital development can mediate the undesirable results of financial constrictions, enabling growth even where bank loans are deficient in some Indian regions. This means that the combined effects of these two variables exceed their individual influence on economic growth. Despite significant progress in explaining how the interaction effects of financial development and human capital may be growth-enhancing, the interaction effects of these two variables on foreign trade remains a matter for empirical investigation. In support of this reasoning, exogenous theories of trade suggest that when foreign capital interacts with foreign labor, it consequently magnifies foreign trade (Rao and Mahale 2011). 


\section{Other factors that affect foreign trade - control variables}

A summary of the determinants of foreign trade is provided in Table 1 below.

Table 1. A summary of the determinants of foreign trade

\begin{tabular}{|c|c|c|}
\hline Variable & Proxy & Reference \\
\hline $\begin{array}{l}\text { Relative size } \\
\text { of economies }\end{array}$ & GDP (real or per capita) & Rahman (2007) \\
\hline Market flexibility & $\begin{array}{l}\text { Flexibility or rigidity of factor of production } \\
\text { variables and related rewards }\end{array}$ & $\begin{array}{l}\text { Uzagalieva and Cukrowski } \\
(2006)\end{array}$ \\
\hline Political factors & $\begin{array}{l}\text { Dummy ( } 1 \text { when preferential trade agreements } \\
\text { exist and zero otherwise), trade barriers }\end{array}$ & $\begin{array}{l}\text { Bordo and Rousseau } \\
(2012)\end{array}$ \\
\hline History & $\begin{array}{l}\text { Existence of colonial ties, common military } \\
\text { alliance, or dummy }\end{array}$ & $\begin{array}{l}\text { Ghanbari and Ahmadi } \\
(2017)\end{array}$ \\
\hline $\begin{array}{l}\text { Linguistic } \\
\text { differences }\end{array}$ & $\begin{array}{l}\text { Dummy ( } 1 \text { if languages are similar and zero } \\
\text { otherwise) }\end{array}$ & Rahman (2007) \\
\hline $\begin{array}{l}\text { Foreign direct } \\
\text { investment }\end{array}$ & Change in foreign direct investment & Mete and Bozgeyik (2017) \\
\hline Interest rate & Change in the real interest rate & Mete and Bozgeyik (2017) \\
\hline $\begin{array}{l}\text { Technological } \\
\text { innovation }\end{array}$ & $\begin{array}{l}\text { Related expenditure, internet hosts, } \\
\text { technological distance }\end{array}$ & Spulber (2008) \\
\hline $\begin{array}{l}\text { Research and } \\
\text { development }\end{array}$ & Research expenditure & $\begin{array}{l}\text { Ghanbari and Ahmadi } \\
(2017)\end{array}$ \\
\hline $\begin{array}{l}\text { Domestic } \\
\text { consumption rate }\end{array}$ & $\begin{array}{l}\text { Increase or decrease in domestic consumption } \\
\text { rate }\end{array}$ & Mete and Bozgeyik (2017) \\
\hline Imported capital & Imports of plant, machinery, and transport & Haq and Luqman (2014) \\
\hline $\begin{array}{l}\text { Preferences and } \\
\text { tastes }\end{array}$ & distance & Rahman (2007) \\
\hline Wealth & $\begin{array}{l}\text { Income levels, domestic earnings, foreign } \\
\text { earnings }\end{array}$ & $\begin{array}{l}\text { Gebrehiwot and Gebru } \\
(2015)\end{array}$ \\
\hline Border sharing & $\begin{array}{l}\text { Dummy ( } 1 \text { if the border is shared or zero } \\
\text { otherwise) }\end{array}$ & Jafari et al. (2011) \\
\hline
\end{tabular}

Source: author's own compilation.

This section of the literature review has shown that there are numerous factors that explain foreign trade apart from the ones at the core of this study. Most of the links formed can be expressed in the form of gravity equations, demonstrating the superiority of gravity models over other trade theories.

\section{Research methodology}

Data and sources: The paper used panel data from 1994 to 2014 to investigate the impact of the interaction between financial development and human capital development on foreign trade in transitional economies. The data for the variables used (foreign 
trade, financial development, human capital development, economic growth, foreign direct investment, infrastructural development) was extracted from World Bank Indicators, the International Monetary Fund (IMF), Africa Development Bank websites, and various United Nations Development Programme reports. Transitional countries involved in the study include Argentina, Colombia, Indonesia, Mexico, South Africa, Turkey, India, and Brazil, following the IMF (2015) report.

Table 2. Shows the correlation results of the study

\begin{tabular}{|l|c|c|c|c|c|c|}
\cline { 2 - 7 } \multicolumn{1}{c|}{} & FT & FIN & HCD & GROWTH & FDI & INFR \\
\hline FT & 1.00 & & & & & \\
\hline FIN & $0.2694^{* * *}$ & 1.00 & & & & \\
\hline HCD & $-0.1884^{* *}$ & $-0.3172^{* * *}$ & 1.00 & & & \\
\hline GROWTH & -0.0747 & 0.0303 & $0.5306^{* * *}$ & 1.00 & & \\
\hline FDI & $-0.1557^{* *}$ & -0.0711 & $0.2713^{* * *}$ & $0.2613^{* * *}$ & 1.00 & \\
\hline INFR & $0.1643^{* *}$ & $0.7415^{* * *}$ & $0.1833^{* * *}$ & $0.4823^{* * *}$ & -0.0314 & 1.00 \\
\hline
\end{tabular}

Note: ${ }^{* * *} /{ }^{* *} /{ }^{*}$ denotes statistical significance at the 1\%/5\%/10\% level, respectively.

Source: author's own compilation from E-Views.

Table 2 shows that both financial development and infrastructural development separately had a significant positive relationship with foreign trade, which is consistent with theoretical predictions. On the other hand, human capital development, economic growth, and FDI were found to have had a separate significant negative relationship with foreign trade, contradicting available theoretical predictions. The maximum size of the relationship between variables (financial development and infrastructural development) is $74.15 \%$, indicating that there is no multicollinearity problem between the variables studied.

Table 3. Descriptive statistics

\begin{tabular}{|l|c|c|c|c|c|c|}
\cline { 2 - 7 } \multicolumn{1}{l|}{} & FT & FIN & HCD & GROWTH & FDI & INFR \\
\hline Mean & 42.7086 & 65.0119 & 0.7195 & 5077.491 & 2.0963 & 1833.511 \\
\hline Median & 45.0900 & 50.4550 & 0.7300 & 4302.440 & 2.0350 & 1718.390 \\
\hline Maximum & 96.1900 & 192.6600 & 0.8800 & 14443.07 & 8.4600 & 5061.200 \\
\hline Minimum & 15.6400 & 19.6600 & 0.4500 & 353.2900 & 0.0700 & 240.0200 \\
\hline $\begin{array}{l}\text { Standard. } \\
\text { deviation }\end{array}$ & 14.5706 & 42.2738 & 0.0852 & 3471.919 & 1.3344 & 1285.066 \\
\hline Skewness & 0.1633 & 1.6908 & -0.5301 & 0.5787 & 1.2173 & 1.004134 \\
\hline Kurtosis & 2.7945 & 4.9810 & 3.0010 & 2.5097 & 5.9956 & 3.252352 \\
\hline Jarque-Bera & 1.0421 & 107.52 & 7.8677 & 11.0603 & 104.3084 & 28.6777 \\
\hline Probability & 0.5939 & 0.0000 & 0.0196 & 0.0040 & 0.0000 & 0.0000 \\
\hline Observations & 168 & 168 & 168 & 168 & 168 & 168 \\
\hline
\end{tabular}

Source: author's own compilation from E-Views. 
According to Table 3, the standard deviation of economic growth from the mean economic growth value and that of infrastructural development from the mean infrastructural development value exceed 1000, indicating the existence of extreme values in these two variables. Financial development, economic growth, FDI, and infrastructural development data are abnormally distributed as they are characterized by zero probability values of the Jarque-Bera criterion. To deal away with problems of abnormally distributed data and extreme values, the current study first transformed all the data sets into natural logarithms before using them for final data analysis, consistent with Tsaurai (2017).

General Model and Econometric Specification: Using the available literature discussed in the earlier sections, the relationship between foreign trade and its determinants can be summarized in the following general model specification.

$$
\mathrm{FT}=\mathrm{f}(\mathrm{FIN}, \mathrm{HCD}, \mathrm{FDI}, \mathrm{GROWTH}, \mathrm{INFR}) \text {. }
$$

Where FT, FIN, HCD, FDI, GROWTH, and INFR are abbreviations for foreign trade, financial development, human capital development, foreign direct investment, economic growth, and infrastructural development, respectively.

In econometric terms, equation 1 can be shown in the form of equation 2 below.

$$
\mathrm{FT}_{\mathrm{it}}=\beta_{0}+\beta_{1} \mathrm{FIN}_{\mathrm{it}}+\beta_{2} \mathrm{HCD}_{\mathrm{it}}+\beta_{3} \mathrm{FDI}_{\mathrm{it}}+\beta_{4} \mathrm{GROWTH}_{\mathrm{it}}+\beta_{5} \mathrm{INFR}_{\mathrm{it}}+\varepsilon i t
$$

Table 4. Signs of equation 2 and their interpretations

\begin{tabular}{|l|l|}
\hline $\mathrm{FT}_{\mathrm{it}}$ & Foreign trade (total trade as a ratio of GDP) in country i at time t \\
\hline $\mathrm{FIN}_{\mathrm{it}}$ & $\begin{array}{l}\text { Financial development (domestic credit by financial sector as a ratio of GDP) in coun- } \\
\text { try i at time } t\end{array}$ \\
\hline $\mathrm{HCD}_{\mathrm{it}}$ & Human capital development (human capital development index) in country $\mathrm{i}$ at time $\mathrm{t}$ \\
\hline $\mathrm{FDI}_{\mathrm{it}}$ & $\begin{array}{l}\text { Foreign direct investment (net foreign direct investment inflow as a ratio of GDP) } \\
\text { in country i at time } \mathrm{t}\end{array}$ \\
\hline GROWTH $_{\mathrm{it}}$ & Economic growth (gross domestic product per capita) in country i at time $\mathrm{t}$ \\
\hline INFR $_{\mathrm{it}}$ & $\begin{array}{l}\text { Infrastructural development [electric power consumption (kWh per capita)] in coun- } \\
\text { try i at time } t\end{array}$ \\
\hline$\varepsilon i t$ & Error term \\
\hline$i$ & Country \\
\hline$t$ & Time \\
\hline$\beta_{0}$ & Intercept term \\
\hline$\beta_{1}$ to $\beta_{5}$ & Co-efficient of the independent variables \\
\hline
\end{tabular}

Source: author's own compilation. 
To determine the influence of the complementarity between financial and human capital development on foreign trade, and interaction term $\beta_{3}$ was introduced in equation 3.

$$
\begin{gathered}
\mathrm{FT}_{\text {it }}=\beta_{0}+\beta_{1} \mathrm{FIN}_{\mathrm{it}}+\beta_{2} \mathrm{HCD}_{\mathrm{it}}+\beta_{3}\left(\mathrm{FIN}_{\mathrm{it}} \cdot \mathrm{HCD}_{\mathrm{it}}\right)+\beta_{4} \mathrm{FDI}_{\mathrm{it}}+ \\
\beta_{5} \mathrm{GROWTH}_{\mathrm{it}}+\beta_{6} \mathrm{INFR}_{\mathrm{it}}+\text { Eit }
\end{gathered}
$$

The following proxies of the variables used were selected in a manner that helps to avoid mixing data problems, which overall has a negative effect on not only the quality but the integrity of the results.

Table 5. Variables, proxy used, and data sources

\begin{tabular}{|l|l|l|}
\hline \multicolumn{1}{|c|}{ Variable } & \multicolumn{1}{|c|}{ Proxy used } & \multicolumn{1}{c|}{ Sources(s) of data } \\
\hline $\begin{array}{l}\text { Foreign trade } \\
\text { (FT) }\end{array}$ & $\begin{array}{l}\text { Total trade } \\
\text { (\% of GDP) }\end{array}$ & $\begin{array}{l}\text { International Monetary Fund databases, World Development } \\
\text { Indicators, African Development Bank databases, and United } \\
\text { Nations Development Programme various reports. }\end{array}$ \\
\hline $\begin{array}{l}\text { Financial } \\
\text { development } \\
\text { (FIN) }\end{array}$ & $\begin{array}{l}\text { Domestic credit } \\
\text { by financial sector } \\
\text { (\% of GDP) }\end{array}$ & $\begin{array}{l}\text { International Monetary Fund databases, World Development } \\
\text { Indicators, African Development Bank databases, and United } \\
\text { Nations Development Programme various reports. }\end{array}$ \\
\hline $\begin{array}{l}\text { Human capital } \\
\text { development } \\
\text { (HCD) }\end{array}$ & $\begin{array}{l}\text { Human capital } \\
\text { development } \\
\text { index }\end{array}$ & $\begin{array}{l}\text { International Monetary Fund databases, World Development } \\
\text { Indicators, African Development Bank databases, and United } \\
\text { Nations Development Programme various reports. }\end{array}$ \\
\hline $\begin{array}{l}\text { Foreign direct } \\
\text { investment } \\
\text { (FDI) }\end{array}$ & $\begin{array}{l}\text { Net FDI inflow } \\
\text { (\% of GDP) }\end{array}$ & $\begin{array}{l}\text { International Monetary Fund databases, World Development } \\
\text { Indicators, African Development Bank databases, and United } \\
\text { Nations Development Programme various reports. }\end{array}$ \\
\hline $\begin{array}{l}\text { Economic } \\
\text { growth } \\
\text { (GROWTH) }\end{array}$ & GDP per capita & $\begin{array}{l}\text { International Monetary Fund databases, World Development } \\
\text { Indicators, African Development Bank databases, and United } \\
\text { Nations Development Programme various reports. }\end{array}$ \\
\hline $\begin{array}{l}\text { Infrastructural } \\
\text { development } \\
\text { (INFR) }\end{array}$ & $\begin{array}{l}\text { Electric power } \\
\text { consumption } \\
\text { (kWh per capita) }\end{array}$ & $\begin{array}{l}\text { International Monetary Fund databases, World Development } \\
\text { Indicators, African Development Bank databases, and United } \\
\text { Nations Development Programme various reports. }\end{array}$ \\
\hline
\end{tabular}

Source: author compilation.

Panel root tests and co-integration: The results are presented in Tables 6 and 7, respectively.

Table 6. Panel root tests - Individual intercept

\begin{tabular}{|l|c|c|c|c|}
\hline \multicolumn{5}{|c|}{ Level } \\
\hline LFT & LLC & IPS & ADF & PP \\
\hline LFIN & -0.8022 & -0.3867 & 15.3166 & $32.1230^{* * *}$ \\
\hline LHCD & $-3.4184^{* * *}$ & $-2.1749^{* *}$ & $29.9143^{* *}$ & $101.744^{* * *}$ \\
\hline LFDI & $-6.1001^{* * *}$ & $-5.2949^{* * *}$ & $57.4886^{* * *}$ & $84.5501^{* * *}$ \\
\hline LGROWTH & $-3.5403^{* * *}$ & $-3.3369^{* * *}$ & $39.7762^{* * *}$ & $55.4211^{* * *}$ \\
\hline
\end{tabular}


Does Financial Development Enhance Foreign Trade in Selected Transitional Economies?

\begin{tabular}{|l|c|c|c|c|}
\hline \multicolumn{5}{|c|}{ Level } \\
\hline & LLC & IPS & ADF & PP \\
\hline LINFR & -0.8898 & 1.5288 & 14.2593 & $25.1836^{*}$ \\
\hline First difference & $-4.2743^{* * *}$ & $-6.5918^{* * *}$ & $72.4081^{* * *}$ & $199.787^{* * *}$ \\
\hline LFT & $-4.0320^{* * *}$ & $-2.9937^{* * *}$ & $36.8941^{* * *}$ & $47.6092^{* * *}$ \\
\hline LFIN & $-11.0672^{* * *}$ & $-10.4702^{* * *}$ & $114.800^{* * *}$ & $1106.98^{* * *}$ \\
\hline LHCD & $-6.5957^{* * *}$ & $-7.96657^{* * *}$ & $87.0560^{* * *}$ & $613.728^{* * *}$ \\
\hline LFDI & $-3.8221^{* * *}$ & $-4.1543^{* * *}$ & $46.0404^{* * *}$ & $86.2116^{* * *}$ \\
\hline LGROWTH & $-7.1645^{* * *}$ & $-5.4011^{* * *}$ & $59.5967^{* * *}$ & $83.3332^{* * *}$ \\
\hline LINFR & & & & 8 \\
\hline
\end{tabular}

Note: LLC, IPS, ADF, and PP stands for Levin, Lin, and Chu (2002); Im, Pesaran, and Shin (2003); ADF Fisher Chi-Square and PP Fisher Chi-Square tests, respectively. * , ** and *** denote 10\%, 5\% and 1\% levels of significance, respectively.

Source: author's own compilation from E-Views.

Table 7. Johansen Fisher Panel Co-integration test

\begin{tabular}{|l|c|c|c|c|}
\hline Hypothesized no. of CE(s) & $\begin{array}{c}\text { Fisher Statistic } \\
\text { (from trace test) }\end{array}$ & Probability & $\begin{array}{c}\text { Fisher Statistic (from } \\
\text { max-eigen test) }\end{array}$ & Probability \\
\hline None & 461.9 & 0.0000 & 211.8 & 0.0000 \\
\hline At most 1 & 258.7 & 0.0000 & 162.3 & 0.0000 \\
\hline At most 2 & 134.1 & 0.0000 & 78.11 & 0.0000 \\
\hline At most 3 & 70.86 & 0.0000 & 45.42 & 0.0001 \\
\hline At most 4 & 40.79 & 0.0006 & 33.92 & 0.0056 \\
\hline At most 5 & 29.19 & 0.0227 & 29.19 & 0.0227 \\
\hline
\end{tabular}

Source: author's compilation from E-Views.

According to Table 6, all the variables were found to be stationary at first difference while using the Johansen Fisher Panel Co-integration test. Table 7 shows that there are at most five co-integrating equations among the variables studied (statistical evidence that there exists a long-run relationship between and among the variables studied). The finding paved the way for the main data analysis (see results in Table 8).

Under fixed effects, financial development had a non-significant positive effect on foreign trade, while random effects showed a significant positive relationship running from financial development towards foreign trade in transitional economies. The findings support the argument by Kumarasamy and Singh (2018) and Brooks and Dovis (2019). By contrast, pooled OLS showed that foreign trade was negatively but significantly affected by financial development, a finding which resonates with Yakubu et al. (2018). A non-significant positive relationship running from human capital development towards foreign trade was detected under the pooled OLS approach, a finding which was supported by Chatterjee (2017). However, both fixed and random effects produced results that show that human capital development had a non-significant negative influence on foreign trade in contrast to the available theoretical literature. The literature (Samuelson 2001; Waugh 2008) argues that human capital stimulates inter- 
national trade. Abundant human capital allows countries to increase production and quality, thereby resulting in an upper hand on moving trade balances. This is not the case for countries low on human capital stock.

Table 8. Panel regression results - The foreign trade function

\begin{tabular}{|l|c|r|c|c|c|c|}
\hline & \multicolumn{2}{|c|}{ Fixed effects } & \multicolumn{2}{c|}{ Random effects } & \multicolumn{2}{c|}{ Pooled OLS } \\
\hline FIN & Co-efficient & t-statistic & Co-efficient & t-statistic & Co-efficient & t-statistic \\
\hline HCD & 0.0531 & 0.8818 & $0.0968^{*}$ & 1.6799 & $-0.2084^{* *}$ & -2.0719 \\
\hline $\begin{array}{l}\text { FTERAC- } \\
\text { TION TERM }\end{array}$ & -0.4326 & -1.0509 & -0.6244 & -1.5879 & 0.4221 & 0.6600 \\
\hline FDI & 0.1645 & 1.2734 & 0.2081 & 1.6414 & $-0.4576^{*}$ & -1.9529 \\
\hline GROWTH & $-0.1757^{* * *}$ & -3.1860 & $-0.0856^{*}$ & -1.8109 & 0.0358 & 0.5164 \\
\hline INFR & $0.7057^{* * *}$ & 5.0991 & $0.3356^{* * *}$ & 3.4644 & 0.0556 & 0.7824 \\
\hline $\begin{array}{l}\text { Adjusted R-squared } 0.7716 \\
\text { F-statistic 44.40 } \\
\text { Prob (F-statistic) } 0.0000\end{array}$ & $\begin{array}{l}\text { Adjusted R-squared } \\
0.6491\end{array}$ & $\begin{array}{l}\text { Adjusted R-squared } \\
\text { F-5928 }\end{array}$ \\
\hline
\end{tabular}

*** $/ * * / *$ indicate $1 \%, 5 \%$ and $10 \%$ significance levels respectively

Source: author's own compilation from E-Views (8).

Human capital development had a significant positive effect on the ability of financial development to enhance foreign trade under both the fixed and random effects approaches. These results do replicate the predictions of the available literature on the subject matter, which, according to Patrick (1966), states that high human capital and financial development quicken the rate of foreign trade. On the other hand, human capital development had a negative influence on financial development's impact on foreign trade under the OLS approach, which contradicts the available theoretical predictions (Lucas 1988; Stokey 1991; Benhabib and Spiegel 1994).

A significant positive impact of FDI on foreign trade was detected under both fixed and random effects, in line with Mete and Bozgeyik (2017). On the other hand, the pooled OLS methodology produced results that show that FDI had an insignificant negative effect on foreign trade. This finding disagrees with most available theoretical predictions on the subject matter.

Pooled OLS noted, however, that the effect of economic growth on foreign trade was positive though non-significant, which is consistent with the study by Rahman (2007). In contrast to the majority of the literature on the subject matter, the influence of economic growth on foreign trade was found to have had a significant negative impact on foreign trade under both the fixed and random effects. Infrastructural development had a significant positive influence on foreign trade under the fixed and random effects, yet the pooled OLS methodology shows a non-significant positive causality running from infrastructural development towards foreign trade. 


\section{Conclusion}

The study investigated the influence of financial development on foreign trade in transitional economies using panel data (1994-2014). Although empirical studies on the impact of financial development on foreign trade are available, none of them that the authors are aware of attempted to explore the subject matter in the context of transitional economies. None of them attempted to investigate if human capital development is a channel through which financial development influence foreign trade or foreign trade. Under fixed effects, financial development was found to have a non-significant positive influence on foreign trade, while the random effects approach shows a significant positive relationship running from financial development towards foreign trade. The finding resonates with the majority of the literature on the subject matter. However, pooled ordinary least squares (OLS) shows that financial development had a significant negative influence on foreign trade.

Under both fixed and random effects, human capital development was found to be a channel through which financial development had a significant positive effect on foreign trade. The results are in line with Patrick's (1966) argument that foreign trade is quickened by high levels of human capital and financial development. The implication of the study is that transitional authorities should develop and implement human capital development enhancement policies in order to enable financial development to have a significant positive effect on foreign trade. In contrast to the available literature, human capital development was found to have had a significant negative impact on foreign trade under the pooled ordinary least squares (OLS) approach. Future studies on the subject matter should address the endogeneity concerns and the dynamic characteristics of foreign trade data. 


\section{References}

Abubakar, A., Kassim, S.H., Yusoff, M.B. (2015), Financial development, human capital accumulation and economic growth: Empirical evidence from the economic community of West African States (ECOWAS), "Procedia-Social and Behavioral Sciences", 172 (January), pp. 96-103. https://doi.org/10.1016/j.sbspro.2015.01.341

Akeem, U.O. (2011), Performance evaluation of foreign trade and economic growth in Nigeria, "Research Journal of Finance and Accounting", 2 (2), pp. 1-15.

Askenazy, P., Caldera, A., Gaulier, G., Irac, D. (2011), Financial Constraints and Foreign Market Entries or Exits: Firm-Level Evidence from France, Working Papers 328, Banque de France. https://doi.org/10.2139/ssrn.1832647

Babatunde, M., Fowowe, B. (2010), Foreign trade and Financial Development Link: Evidence from Sub-Saharan Africa, "Journal of Economic Management", 7 (1), pp. 1-15.

Baldwin, R., Krugman, P. (1989), Persistent trade effects of large exchange rate shocks, "The Quarterly Journal of Economics”, 104 (4), pp. 635-654. https://doi.org/10.2307/2937860

Beck, T. (2002), Financial development and foreign trade: Is there a link?, "Journal of International Economics”, 57 (1), pp. 107-131. https://doi.org/10.1016/S0022-19 96(01)00131-3

Becker, B., Chen, D., Greenberg, J. (2013), Financial development, fixed costs and foreign trade, "Review of Corporate Finance Studies", 2 (1), pp. 1-28. https://doi.org /10.1093/rcfs/cfs005

Bellone, F., Musso, P., Nesta, L., Schiavo, S. (2010), Financial constraints and firm export behaviour, "The World Economy”, 33 (3), pp. 347-373. https://doi.org/10.1111 /j.1467-9701.2010.01259.x

Benhabib, J., Spiegel, M.M. (1994), The role of human capital in economic development evidence from aggregate cross-country data, "Journal of Monetary Economics”, 34 (2), pp. 143-173. https://doi.org/10.1016/0304-3932(94)90047-7

Berman, N., Héricourt, J. (2010), Financial factors and the margins of trade: Evidence from cross-country firm-level data, "Journal of Development Economics", 93 (2), pp. 206-217. https://doi.org/10.1016/j.jdeveco.2009.11.006

Bordo, M., Rousseau, P. (2012), Historical Evidence on the Finance-Trade-Growth Nexus, "Journal of Banking and Finance", 36 (4), pp. 1236-1243. https://doi.org/10.10 16/j.jbankfin.2011.11.012

Brooks, W., Dovis, A. (2019), Credit market frictions and trade liberalizations, "Journal of Monetary Economics", 27 (3), pp. 1-16.

Cartiglia, F. (1997), Credit constraints and human capital accumulation in the open economy, "Journal of International Economics", 43 (1-2), pp. 221-236. https://doi .org/10.1016/S0022-1996(96)01469-9

Chatterjee, A. (2017), Endogenous comparative advantage, gains from trade and symmetry-breaking, "Journal of International Economics", 109 (November), pp. 102-115. https://doi.org/10.1016/j.jinteco.2017.08.009

Choi, B. (2018), Financial development, endogenous dependence on external financing, and trade, "Economica", March, pp. 1-58.

Domenico, S., Emiliano, C., Alina, C. (2009), Human Capital and Openness to Foreign Trade: Evidence from the Enlarged Europe, "Analele Universităţii Din Oradea", 7 (3), pp. 36-55. 
Edoumiekumo, S.G., Opukri, C.O. (2013), Economic growth factor in Nigeria: the role of global trade, "American Journal of Humanities and Social Sciences", 1 (2), pp. 51-55. https://doi.org/10.11634/232907811301303

Engel, D., Procher, V., Schmidt, C. (2013), Does firm heterogeneity affect foreign market entry and exit symmetrically? Empirical evidence from French firms, "The Word Economy”, 85 (1), pp. 37-47. https://doi.org/10.1016/j.jebo.2012.10.016

Eryigit, S.B., Dulgeroglu, E. (2015), How to Measure the Level of Financial Development, [in:] Handbook of Research on Strategic Developments and Regulatory Practice in Global Finance, IGI Global, United States, pp. 260-286. https://doi.org/10.40 18/978-1-4666-7288-8.ch017

Evans, D., Green, C., Murinde, V. (2002), Human capital and financial development in economic growth: New evidence using the Translog Production Function, "International Journal of Finance and Economics", 7 (2), pp. 123-140. https://doi.org/10 $.1002 /$ ijfe. 182

Ezeoha, A.E., Cattaneo, N. (2012), FDI flows to Sub-Saharan Africa: the impact of finance, institutions and natural resource endowment, "Comparative Economic Studies”, 54 (3), pp. 597-632. https://doi.org/10.1057/ces.2012.18

Fauceglia, D. (2015), Credit constraints, firm exports and financial development: Evidence from developing countries, "The Quarterly Review of Economics and Finance", 55 (February), pp. 53-66. https://doi.org/10.1016/j.qref.2014.08.003

Forlani, E. (2010), Liquidity constraints and firm's export activity, Centro Studi Luca d'Agliano Working Papers 291. https://doi.org/10.2139/ssrn.1646950

Gebrehiwot, G., Gebru, B. (2015), Ethiopia's foreign trade potential: Inferences from a dynamic gravity approach, "International Journal of Economics and Business Research", 9 (4), pp. 355-375. https://doi.org/10.1504/IJEBR.2015.069667

Ghanbari, A., Ahmadi, M. (2017), The Effect of Innovation on Foreign trade: Selected Medium-High-Technology Industries, Evidence on Iran, "Iranian Economic Review", 21 (1), pp. 21-44.

Gokmenoglu, K.K., Amin, M.Y., Taspinar, N. (2015), The relationship among foreign trade, financial development and economic growth: the case of Pakistan, "Procedia Economics and Finance”, 25, pp. 489-496. https://doi.org/10.1016/S2212-5671(15) 00761-3

Grossman, G.M., Helpman, E. (1991), Trade, knowledge spill overs, and growth, "European Economic Review”, 35 (2-3), pp. 517-526. https://doi.org/10.1016/0014-292 1(91)90153-A

Hakeem, M., Oluwatoyin, O. (2012), Financial development and human capital in South Africa: a time-series approach, "Research in Applied Economics", 4 (3), pp. 18-38. https://doi.org/10.5296/rae.v4i3.1498

Hanh, P.T.H. (2010), Financial development, financial openness and trade openness: New evidence, FIW working paper Number 60.

Haq, M., Luqman, M. (2014), The contribution of foreign trade to economic growth through human capital accumulation: Evidence from nine Asian countries, "Cogent Economics and Finance”, 2 (1), 947000. https://doi.org/10.1080/23322039.2014.94 7000 
Hassan, A.K., Islam, M.R. (2005), Temporal causality and dynamics of financial development, trade openness, and economic growth in Vector Auto Regression (VAR) for Bangladesh, 1974-2003: Implication for poverty reduction, "Journal of Nepalese Business Studies”, 2 (1), pp. 1-12. https://doi.org/10.3126/jnbs.v2i1.50

Hur, J., Raj, M., Riyanto, Y.E. (2006), Finance and trade: A cross-country empirical analysis on the impact of financial development and asset tangibility on foreign trade, "World Development", 34 (10), pp. 1728-1741. https://doi.org/10.1016/j.worlddev.20 06.02 .003

Im, K.S., Pesaran, M.H., Shin, Y. (2003), Testing unit roots in heterogeneous panels, "Journal of Econometrics", 115 (1), pp. 53-74. https://doi.org/10.1016/S0304-4076 (03)00092-7

International Monetary Fund (2015), World Economic Outlook: Adjusting to Lower Commodity Prices, Washington (October).

Jafari, Y., Ismail, M.A., Kouhestani, M.S. (2011), Determinants of trade flows and D8 countries: Evidence from the Gravity Model, "Journal of Economic Cooperation and Development”, 32 (3), pp. 21-38.

Kargbo, A.A., Ding, Y., Kargbo, M. (2016), Financial development, human capital and economic growth: New evidence from Sierra Leone, "Journal of Finance and Bank Management", 4 (1), pp. 49-67.

Kendall, J. (2007), The importance of local finance and human capital in regional growth: The case of India, University of California Santa Cruz, Job Market Paper.

Kiendrebeogo, Y. (2013), How do banking crises affect bilateral exports?, "Empirical Economics", 150, pp. 1-29. https://doi.org/10.5089/9781475576276.001

Kumarasamy, D., Singh, P. (2018), Access to finance, financial development and firm ability to export: experience from Asia-Pacific countries, "Asian Economic Journal”, 32 (1), pp. 15-38. https://doi.org/10.1111/asej.12140

Leibovici, F. (2018), Financial development and foreign trade, Federal Reserve Bank of St. Louis, Working Paper 2018-015A. https://doi.org/10.20955/es.2018.13

Levin, A., Lin, C.F., Chu, C.S.J. (2002), Unit root tests in panel data: Asymptotic and finite-sample properties, "Journal of Econometrics", 108 (1), pp. 1-24. https://doi.org /10.1016/S0304-4076(01)00098-7

Lucas, R.E. (1988), On the Mechanics of Economic Development, "Journal of Monetary Economics”, 22 (1), pp. 3-42. https://doi.org/10.1016/0304-3932(88)90168-7

Manova, K. (2013), Credit constraints, heterogeneous firms, and foreign trade, "Review of Economic Studies”, 80 (1), pp. 711-744. https://doi.org/10.1093/restud/rds036

Mete, M., Bozgeyik, Y. (2017), An Empirical Investigation on Determinants of Foreign Trade in Turkey, "Expert Journal of Economics", 5 (1), pp. 27-37.

Minetti, R., Zhu, S. (2011), Credit constraints and firm export: microeconomic evidence from Italy, "Journal of International Economics", 83 (1), pp. 109-125. https://doi.org /10.1016/j.jinteco.2010.12.004

Muûls, M. (2012), Exporters, importers and credit constraints. Centre for Economic Performance, National Bank of Belgium Working Paper Number 139, October 2012.

Owen, A.L. (1999), Foreign trade and the accumulation of human capital, "Southern Economic Journal”, 66 (1), pp. 61-81. https://doi.org/10.2307/1060835 
Paravisini, D., Rappoport, V., Schnabel, P., Wolfenson, D. (2011), Dissecting the effect of credit supply on trade: Evidence from matched credit-export data, NBER Working Paper 16975. https://doi.org/10.3386/w16975

Patrick, H.T. (1966), Financial development and economic growth in underdeveloped countries, "Economic Development and Cultural Change", 14 (2), pp. 174-189. https://doi.org/10.1086/450153

Rajan, R., Zingales, L. (1998), Financial dependence and growth, "American Economic Review", 88 (3), pp. 559-586.

Rao, D.T., Mahale, K. (2011), Growth in Exports of Services of India Exogenous Human Capital, Labor Market Infirmities and Complementing Foreign Capital, "Transnational Corporations Review”, 3 (3), pp. 106-123. https://doi.org/10.1080/19186444 .2011 .11658301

Samuelson, P.A. (2001), A Ricardo-Sraffa paradigm comparing gains from trade in inputs and finished goods, "Journal of Economic Literature", 39 (4), pp. 1204-1214. https://doi.org/10.1257/jel.39.4.1204

Schumpeter, J.A. (1934), The Theory of Economic Development: An Inquiry FTo Profits, Capital, Credit, interest, and the Business Cycle, Transaction Books, New Brunswick.

Sehrawat, M., Giri, A.K. (2014), The relationship between financial development indicators and human development in India, "International Journal of Social Economics", 41 (12), pp. 1194-1208. https://doi.org/10.1108/IJSE-11-2013-0268

Shahbaz, M., Rahman, M.M. (2014), Exports, financial development and economic growth in Pakistan, "International Journal of Development Issues", 13 (2), pp. 155 170. https://doi.org/10.1108/IJDI-09-2013-0065

Spulber, D.F. (2008), Innovation and foreign trade in technology, "Journal of Economic Theory”, 138 (1), pp. 1-20. https://doi.org/10.1016/j.jet.2007.06.002

Stokey, N.L. (1991), Human capital, product quality, and growth, “The Quarterly Journal of Economics”, 106 (1), pp. 587-616. https://doi.org/10.2307/2937948

Tsaurai, K. (2017), Is foreign portfolio equity investment inspired growth hypothesis relevant in emerging markets?, "Euro Economica", 36 (2), pp. 78-90.

Tsaurai, K. (2018), Is the interaction between human capital and financial development one of the determinants of FDI in emerging markets?, "International Journal of Education Economics and Development", 9 (1), pp. 24-37. https://doi.org/10.1504/IJ EED.2018.10012161

Ukenna, S., Ijeoma, N., Anionwu, C., Olise, M. (2010), Effect of Investment in Human Capital Development on Organisational Performance: Empirical Examination of the Perception of Small Business Owners in Nigeria, "European Journal of Economics, Finance and Administrative Sciences”, 1 (26), pp. 93-107.

Uzagalieva, A., Cukrowski, J. (2006), Labor Market Flexibility, International Competitiveness and Patterns of Trade, "International Economics", 59 (2), pp. 225-246.

Vaubourg, A.G. (2016), Finance and foreign trade: A review of the literature, "Revue d'économie politique", 126 (1), pp. 57-87. https://doi.org/10.3917/redp.261.0057

Waqas, M., Shaheen, S., Awan, M.S., Aslam, M.A. (2011), Financial Development, Foreign trade and Economic Growth: Empirical Evidence from Pakistan, MPRA Paper No. 32876. https://doi.org/10.2139/ssrn.1950013 
Waugh, M.E. (2008), Human capital, product quality, and bilateral trade, Federal Reserve Bank of Minneapolis, Minnesota.

Yakubu, A.S., Aboagye, A.Q., Mensah, L., Bokpin, G.A. (2018), Effect of financial development on foreign trade in Africa: Does measure of finance matter?, "The Journal of Foreign Trade and Economic Development”, 27 (8), pp. 917-936. https://doi.org /10.1080/09638199.2018.1474246

Zaman, K., Izhar, Z., Mushtag Khan, M., Ahmad, M. (2012), The relationship between financial indicators and human development in Pakistan, "Economic Modeling", 29 (5), pp. 1515-1523. https://doi.org/10.1016/j.econmod.2012.05.013

\section{Streszczenie}

\section{Czy rozwój finansowy wpływa na rozwój handlu zagranicznego w wybranych gospodarkach przejściowych?}

W opracowaniu zbadano wpływ rozwoju finansowego na handel zagraniczny w gospodarkach przejściowych z wykorzystaniem danych panelowych (dla lat 1994-2014). Chociaż dostępne są badania empiryczne dotyczące wpływu rozwoju finansowego na handel zagraniczny, żadne ze znanych autorom badań nie stanowiło próby zgłębienia tematu w odniesieniu do gospodarek przejściowych. Nie podjęto próby zbadania, czy rozwój kapitału ludzkiego jest kanałem, poprzez który rozwój finansowy wpływa na handel zagraniczny lub handel międzynarodowy. W przypadku podejścia opartego o efekty stałe stwierdzono, że rozwój finansowy nie ma istotnego pozytywnego wpływu na handel zagraniczny, podczas gdy podejście oparte o efekty losowe wskazuje na istotną pozytywną zależność między rozwojem finansowym a handlem zagranicznym. Ustalenia te są zbieżne z większością literatury przedmiotu. Jednakże, metoda pooled OLS wskazuje, że rozwój finansowy miał znaczący negatywny wpływ na handel zagraniczny.

Zarówno w przypadku podejścia opartego o efekty stałe, jak i losowe, rozwój kapitału ludzkiego okazał się kanałem, przez który rozwój finansowy miał istotny pozytywny wpływ na handel zagraniczny. Wyniki ten są zgodne z argumentacją Patricka (1966), że handel zagraniczny jest napędzany przez wysoki poziom kapitału ludzkiego i rozwoju finansowego. Z badania wynika, że władze państw przejściowych powinny opracować i wdrożyć politykę rozwoju kapitału ludzkiego, tak aby rozwój finansowy miał znaczący pozytywny wpływ na handel zagraniczny. W przeciwieństwie do dostępnej literatury, niniejsze badanie wykazało, że rozwój kapitału ludzkiego miał znaczący negatywny wpływ na handel zagraniczny przy zastosowaniu podejścia OLS. Przyszłe badania na ten temat powinny uwzględniać kwestie związane z endogennością i dynamicznym charakterem danych dotyczących handlu zagranicznego.

Słowa kluczowe: rozwój finansowy, handel zagraniczny, gospodarki przejściowe, dane panelowe

JEL: G15, J24, P45, P2 